\title{
OWNERSHIP VERSUS ENVIRONMENT: WHY ARE PUBLIC SECTOR FIRMS INEFFICIENT?
}

\author{
Ann P. Bartel \\ Ann E. Harrison \\ Working Paper 7043 \\ http://www.nber.org/papers/w7043
NATIONAL BUREAU OF ECONOMIC RESEARCH 1050 Massachusetts Avenue
Cambridge, MA 02138
March 1999

The authors thank the Chazen Institute and the World Bank for financial support for this project. We would also like to thank Glenn Hubbard, Michael Kirschenheiter, and seminar participants at the NBER productivity lunch, Columbia Business School Finance Free Lunch, the New York Federal Reserve Bank, New York University, and Copenhagen Business School's June 1998 Conference for useful comments and suggestions. The views expressed in this paper are those of the authors and do not reflect those of the National Bureau of Economic Research.

( 1999 by Ann P. Bartel and Ann E. Harrison. All rights reserved. Short sections of text, not to exceed two paragraphs, may be quoted without explicit permission provided that full credit, including ${ }^{\circledR}$ notice, is given to the source. 
Ownership versus Environment:

Why Are Public Sector Firms Inefficient?

Ann P. Bartel and Ann E. Harrison

NBER Working Paper No. 7043

March 1999

JEL No. L33, D24

\section{ABSTRACT}

In this paper we disentangle the sources of public sector inefficiency using 1982-1995 panel data on manufacturing firms in Indonesia. We consider two leading hypotheses: (1) public sector enterprises are inefficient due to monitoring problems and (2) public sector enterprises are inefficient because of the environment in which they operate, as measured by the soft budget constraint. The two models are nested in a production function framework and the empirical results provide support for the second hypothesis. Public sector enterprises are inefficient because of their access to soft loans; public sector ownership has no independent impact on productivity growth. The finding that ownership per se does not matter, but environment does, holds when we control for fixed effects and when we allow for the endogeneity of government loans. Interestingly, private sector firms with access to government loans did not perform more poorly than other private sector enterprises. Another dimension of the environment, i.e. import penetration, also matters; public sector enterprises that have been shielded from import competition are inferior performers.

Ann P. Bartel

Graduate School of Business

Columbia University

710 Uris Hall

New York, N.Y. 10027

and NBER

apb2@columbia.edu
Ann E. Harrison

Graduate School of Business

Columbia University

615 Uris Hall

New York, N.Y. 10027

and NBER

aeh14@columbia.edu 
"The argument for privatizing the corporation, of course, is that private owners, driven by the profit incentive, will operate the company more efficiently."

-- Louis Uchitelle, The New York Times, May 31, 1998.

"Few privatized companies have become more efficient or profitable".

-- Venyamin Sokolov on Russia, The New York Times, June 1, 1998.

Why privatize? One primary objective of privatization is to enhance the efficiency of public enterprises. This is the perspective put forth by Louis Uchitelle in an interview with Joseph Stiglitz in last May's New York Times. One day later, an editoral by the director of Russia's General Accounting Office appeared, pointing out that very few of Russia's privatized firms have actually increased efficiency. Clearly, the evidence to date on the superior performance of privatized plants is incomplete. Megginson et al.(1994) conclude their review of the evidence by stating that the wave of privatizations carried out over the last decade were based on blind faith. Laffont and Tirole, in their (1993) book, echo that point, remarking that "the empirical literature on the relative efficiency of the two ownership structures is itself currently inconclusive". Although many studies find that public sector plants perform poorly relative to their private sector counterparts (Boardman and Vining (1989), Kikeri, Nellis, and Shirley (1992), La Porta and Lopez-de-Silanes (1997)), other studies get mixed or ambigious results (Funkhouser and MacAvoy (1979), Groves, Hong, McMillan and Naughton (1994)).

One explanation for the conflicting evidence is that the efficiency gains from privatization depend on a variety of factors, including the degree of competition, the regulatory environment, 
the magnitude of market failure, and the administrative capabilities of the government. These are the conclusions reached by Vickers and Yarrow (1991), in their lengthy review of the arguments for and against privatization. One recent article which provides a formal argument for this view is Shleifer and Vishny (1994). They present a model of bargaining between politicians and managers and show that privatization enhances efficiency only if "control rights" over employment decisions are shifted to the plant manager and government subsidies are targetted at inefficient public plants. This perspective focuses on the environment in attempting to explain the performance of public and private enterprises.

Others, however, argue that private sector ownership is always inferior to public sector ownership, even after controlling for differences in the environment. These types of arguments, as illustrated by Ehrlich et al (1994), are often based on some variant of a principal agent problem: the principal (the government) either cannot or does not choose to properly monitor the managers. This approach focuses on ownership as the explanation for poor public sector performance. ${ }^{1}$

Despite these different perspectives, the empirical studies on privatization have typically focused on identifying the magnitude of the gains, rather than attempting to identify their sources. Recent papers (Megginson et al (1994), Boubakri and Cosset (1998)) compare performance in a set of enterprises before and after privatization, but do not control for the conditions under which

\footnotetext{
${ }^{1}$ The importance of the principal-agent problem is also demonstrated by Gertner, Scharfstein and Stein (1994) who show how an internal capital market where corporate headquarters owns the business units to which it allocates capital leads to more monitoring compared to the situation of external financing where the bank does not own the firms to which it lends. Hubbard and Palia (1999) use the internal capital market hypothesis to explain why bidding firms earned positive abnormal returns in diversifying acquisitions in the 1960s.
} 
these privatizations occurred. From a policy perspective, however, it is critical to be able to identify the determinants of improved performance with privatization. For example, if public sector enterprises perform poorly because they are located in sectors with very little internal or external competition, or because of access to soft loans, then public sector plants could be induced to behave like the private sector in a competitive, subsidy-free environment. Conversely, privatization without competition could lead to a decline in efficiency.

One recent paper (LaPorta and Lopez-de-Silanes, 1997) does examine the sources of public sector inefficiency. Using data for all 218 non-financial privatizations that took place in Mexico between 1983 and 1991, LaPorta and Lopez-de-Silanes decompose the post-privatization improvement in the ratio of operating income to sales and show that 10 percent is due to higher product prices, 33 percent to transfers from laid-off workers and the remaining 57 percent to productivity gains. Our analysis suggests that these observed productivity gains and reductions in employment-at least in the Indonesian case--are primarily due to reductions in government subsidies and increasing import competition.

In this paper, we focus on the role of ownership versus the environment and attempt to assign a relative weight to these two explanations for poor public sector behavior. ${ }^{2}$ Although many regulatory aspects cannot be adequately captured in our empirical work, we do measure two important environmental factors: (1) the role of soft budget constraints and (2) the degree of internal and external competition. We also control for stock market participation, which some

\footnotetext{
${ }^{2}$ In contrasting the roles of ownership and environment we do not distinguish between different types of owners post-privatization, i.e. our focus is on private vs. public owners. Barberis et.al. (1996) study the restructuring that occurred in privatized Russian shops when there were new owners and new managers compared to giving equity to the old managers.
} 
researchers have argued could act as a monitoring device for public and private sector enterprises. Previous work (Pinto and Van Wijnbergen (1995), Claessens and Djankov (1997)) has studied the effect of soft loans on performance, but has not identified their importance in explaining the relative performance of public versus private firms.

To identify the sources of public sector inefficiency, we use a 1981-1995 panel of all public and private enterprises in manufacturing in Indonesia. Our results suggest that in recent years, all of the observed inferior performance of publicly owned manufacturing enterprises in Indonesia is attributable to plants which received loans from state banks and plants which were shielded from import competition. These results suggest that in Indonesia, the environment has played a more important role than any independent effect of ownership per se. Section II reviews a number of hypotheses regarding public sector efficiency and sets up the empirical framework for the paper. Section III discusses the data, Section IV presents the results, and Section V concludes.

\section{Theoretical Background and Empirical Implementation}

\section{A. Theoretical Background}

Although there have been many articles written on the benefits and costs of privatization, two articles provide the theoretical motivation for our work. The first is a paper by Shleifer and Vishny (1994) which presents a model of bargaining between politicians and managers and shows the conditions under which privatization will lead to increased productivity. Shleifer and Vishny (1994) argue that government officials are willing to subsidize public enterprises only to the extent that they hire workers beyond the profit-maximizing level. Public enterprises are granted 
subsidies in return for promising to hire too many workers. There is a direct negative link between government transfers and plant productivity, since government officials "pay" enterprise managers to hire too many workers.

In this framework, privatization is defined as shifting control over "cash flow" to the enterprise. However, by placing the firm's equity in private hands, the government does not necessarily relinquish control over hiring decisions. This type of control is referred to as "control rights". The authors show that privatization alone need not lead to any increases in efficiency (ie a reduction in excess workers). In fact, privatization could be associated with falling efficiency if politicians retain control rights. This would be the case for a regulated firm, where cash flow is privatized but control rights remain with the government.

The second article that provides a theoretical framework for our empirical work is Ehrlich et.al. (1994). In their model, the level of total factor productivity is a function of managerial time allocated to current production, while the rate of total factor productivity growth is positively related to the manager's commitment to investments in plant-specific capital. Public sector managers, according to their model, spend too much time pursuing independent private objectives. This has two effects: it reduces the time spent building plant-specific capital (which raises TFP growth in the long run); but it will increase the time spent monitoring current production (by definition), raising the current level of TFP. This framework implies that there is no reason why levels of productivity in public sector plants should be lower than in the private sector in the short run, but it does imply a lower rate of productivity growth for public sector enterprises. In the longer term, of course, lower public sector productivity growth should eventually lead to lower productivity levels than in the private sector. 
Ehrlich et al (1994) is typical of most work that addresses the issue of public versus private efficiency: public enterprises are assumed to be less efficient in the long run because the managers fail to act in a way that maximizes long run profits. Although Ehrlich et al do not say why, one reason could be imperfect monitoring by the government. This paper is one illustration of a wider literature which argues that public sector enterprises are by their nature more inefficient--primarily due to principal agent problems. One implication is that there should be a consistent negative coefficient on public ownership in any comparisons of productivity growth. Shleifer and Vishny (1994), on the other hand, argue that ownership changes by themselves are generally not associated with any change in performance. According to to this alternative framework, it is the environment which determines the comparative performance of the two types of enterprises.

\section{B. Some Preliminary Evidence}

Before we outline our empirical approach, we begin by reporting some preliminary evidence on privatizing plants in Indonesia. Our dependent variables include a number of measures used by other authors to assess the impact of privatization on performance, including the ratio of operating income to sales, net income to sales, the log of sales, the log of sales per employee, operating income per employee, the log of cost per unit, and the log of employees. Variable definitions are included at the bottom of Table 1; we use similar variables to those reported in LaPorta and Lopes de Silanes (1997).

We regress these different measures of performance on two variables for the time period 1981-1995: (1) the change in public ownership, which varies from 0 to 100 percent and (2) the change in access to soft loans, which is measured as the percentage of the plant's investments 
which were financed with government loans. Our econometric approach is to use a within regression, where both the dependent and independent variables are transformed into deviations from their within-plant mean. This allows us to sweep out any unobserved fixed effect, such as the importance of age, location, unmeasured manager ability, etc. We only include in the sample plants which privatized 100 percent. Later in the paper, we include all plants, both public and private, which provides us with a control group for privatizing plants.

If ownership and government loans are entered individually in the regressions, the results in Table 1 suggest that both privatization and reductions in government loans are significantly associated with improvements in performance. If we do not control for access to government loans, reductions in public sector ownership are significantly associated with improvements in profitability, sales, operating income per employee, reductions in unit costs, and reductions in the number of employees. Entered individually, reductions in government loans are also associated with improvements in performance.

If we introduce both changes in ownership and changes in government loans in the regressions, then in the majority of cases the importance of ownership changes disappear. The results in Table 1 appear to suggest that most of the gains observed from privatization occur through a reduction in access to soft loans. This is true if we measure performance as log of sales or log of sales per employee, reductions in cost per unit, or reductions in the number of employees. Improvements in operating income relative to sales or employees, however, seems to be primarily associated with reductions in public sector ownership. The results in Table 1 suggest that there are other factors associated with the gains from privatization which go beyond simply changing ownership. In particular, the results suggest that many of the observed gains associated 
with privatization are linked with a more rigorous environment. In the remainder of the paper, we explore those factors more carefully.

An important consideration for any analysis of the gains from privatization is whether the better-performing public enterprises are targetted for privatization. In order to test this hypothesis for Indonesia, we re-estimated the equations in Table 1 adding a dummy for the time period just prior to privatization. In all cases, this dummy variable was insignificant indicating that in Indonesia there is no evidence that firms were selected for privatization based on their performance. Hence, in the remainder of the paper, we treat privatization as an exogenous variable.

\section{Measuring Total Factor Productivity Growth (TFPG)}

As our yardstick of relative performance, we focus exclusively on total factor productivity growth (TFPG) because prior research (La Porta and Lopez-de-Silanes, 1997) has shown that a very large of the gains from privatization is due to productivity growth. We begin with a general discussion of the problems involved in production function estimation, and then discuss in turn how to introduce the role of soft budgets and ownership. A general production function for plant $\mathrm{i}$ in sector $\mathrm{j}$ at time $\mathrm{t}$ is given by equation (1):

$Y_{i j t}=A_{i j t} F\left(Z_{i j t}\right)$

Output $Y_{i j t}$ is a real measure of plant-level output and $Z$ is a vector of $M$ inputs. In our estimation, we will include as inputs both skilled and unskilled labor, capital inputs, and materials. $A_{i j t}$ is a plant-specific index of Hicks-neutral technical progress which will depend on a number of factors, 
including ownership. Totally differentiating (1), and dividing through by $Y$, we have

$$
d Y / Y_{i j t}=\sum_{m}\left(\partial Y / \partial Z_{m}\right)\left(d Z_{m} / Y\right)_{i j t}+d A / A_{i j t}
$$

In this framework, imperfect competition enters (2) because plants with market power do not set the value marginal product $P(\partial Y / \partial Z)$ equal to the factor price. If we assume Cournot behavior by imperfectly competitive plants, then we can derive the first order conditions from each plant's profit maximization and write each of the partial derivatives $\partial Y / \partial Z$ :

$$
\left(\partial Y / \partial Z_{m}\right)_{i j t}=\left(w_{m} / p\right)_{j t}\left[\frac{1}{1+\left(S_{i j} / e_{j}\right)}\right]=\left(w_{m} / p\right)_{j t} \mu_{i j}
$$

$S$ is the ith plant's share in the jth industry, while $e$ is the elasticity of demand. Factor prices for input $\mathrm{m}$ are given by $\mathrm{w}_{\mathrm{m}}$. If plant $\mathrm{i}$ is not perfectly competitive, then the value of the marginal product exceeds the factor cost by some mark-up $\mu$. For simplicity, we will assume that the mark-up parameter does not vary across plants or over time.

Substituting (3) into (2) and rearranging terms, we have

$$
d Y / Y_{i j t}=\mu_{j} \sum_{m}\left[w_{m} Z_{m} / P Y \frac{d Z_{m}}{Z_{m}}\right]+(d A / A)_{i j t}
$$


The value of $w_{m} Z_{m} / P Y$ is the share of the mth factor in total output. We shall denote this share as $\mathrm{B}_{m}$. Rewriting (4),

$d \ln Y_{i j t}=d \ln A_{i j t}+\mu \sum_{m=1 \text { to } M} \mathrm{~B}_{m} d \ln Z_{m i j t}$

All variables have been rewritten in log form. Output growth can be decomposed into two sources: growth in productivity, or growth in input use. In a regression framework, the coefficients on the $M$ inputs include two components: the mark-up parameter $\mu$, and the factor share. By not constraining the coefficients, we allow both factor shares and mark-ups to vary. To simplify the presentation, we will now omit subscripts in most of the discussion which follows.

\section{Introducing the Soft Budget Constraint}

To introduce the importance of the soft budget constraint, we draw from the intuition provided by Shleifer and Vishny (1994). In their model, politicians and managers bargain over the level of employment in the firm. Politicians offer managers some amount of transfer, T, to induce them to hire extra labor. Shleifer and Vishny assume that this excess labor produces no extra output. This means that there is a direct link between $\mathrm{T}$ and lower productivity: firms which take more $\mathrm{t}$ and consequently hire more excess labor will have lower productivity. Our goal is to capture this effect empirically.

Consistent with their framework, we can assume that there are two types of labor: necessary labor (NL) and excess labor (EL). If EL is included with other labor inputs, estimation of the production function will show that firms with more EL have lower productivity growth. To the extent that firms with EL also tend to be public sector enterprises, we could conclude that 
public sector enterprises are more inefficient. If we can isolate labor inputs (EL) which are tied to transfers, however, then we can separate the impact of ownership from the soft budget constraint on productivity.

Unfortunately, however, we do not observe EL and NL separately. If we isolate labor inputs from other inputs, we can rewrite equation (5) as follows:

$d \ln (Y)=d \ln A+\mu \mathrm{B}_{N L+E L} d \ln (N L+E L)+\sum_{m=2 \text { to } M} \mu \mathrm{B}_{m} d \ln \left(Z_{m}\right)$

We only observe total labor inputs, given by the sum of NL and EL, as well as the total share of labor, given by $\mathrm{B}_{\mathrm{NL}+\mathrm{EL}}$. Suppose we could isolate necessary from excess labor. Then we could define "true" TFPG, which is the residual $d \ln A$, as:

$d \ln A_{\text {true }}=T F P G_{\text {true }}=d \ln (Y)-\mu \mathrm{B}_{N L} d \ln (N L)-\sum_{m=2 \text { to } M} \mu \mathrm{B}_{m} d \ln \left(Z_{m}\right)$

However, since the plant has employees who do nothing, observed TFPG will in fact be lower:

$d \ln A_{\text {observed }}=T F P G_{\text {observed }}=d \ln (Y)-\mu \mathrm{B}_{N L+E L} d \ln (N L+E L)-\sum_{m} \mu \mathrm{B}_{m} d \ln \left(Z_{m}\right)$

If we assume that necessary and unnecessary labor are paid the same wage, simple algebra shows that the difference between (7) and (7)' is given by the following:

$T F P G_{\text {observed }}=T F P G_{\text {true }}-\mu \mathrm{B}_{N L+E L}\{d E L /(N L+E L)\}$ 
Observed TFPG for plants receiving transfers has two components--the component which measures actual technological change in the plant, and the component attributed to excess labor. So observed TFPG in plants which receive transfers will always be lower, due to the negative contribution of excess labor.

Ideally, we would like to be able estimate both true productivity growth, $d \ln \mathrm{A}_{\text {true, }}$, as well as the contribution due to hiring excess labor. We can do this by estimating equation (8):

$$
\begin{aligned}
d \ln (Y) & =d \ln A_{\text {true }}+\mu \mathrm{B}_{N L+E L} d \ln (N L+E L)+\sum_{m=2 \text { to } M} \mu \mathrm{B}_{m} d \ln \left(Z_{m}\right)-\mu \mathrm{B}_{N L+E L}\{d E L /(N L+E L)\} \\
& =d \ln A_{\text {true }}+\sum_{m=1 \text { to } M} \mu \mathrm{B}_{m} d \ln \left(Z_{m}\right)-\mu \mathrm{B}_{N L+E L}\{d E L /(N L+E L)\}
\end{aligned}
$$

We can now directly estimate the negative contribution of excess labor inputs to observed TFPG, which is captured by $\mu \mathrm{B}_{\mathrm{NL}+\mathrm{EL}}\{\mathrm{dEL} /(\mathrm{NL}+\mathrm{EL})\}$. However, since EL is unobserved, we need a proxy for the change in the amount of "excess" labor. To derive an expression for excess labor, we modify the model outlined by Shleifer and Vishny in their 1994 QJE (hereafter referred to as SV). Politicians use government funds, which in their model are labelled as transfers T, to get managers to hire more employees than is necessary. These excess employees are labeled EL and are paid a (real) wage w. Politicians maximize a utility function equal to the benefits from providing more jobs $(\mathrm{B}(\mathrm{EL}))$ less the costs of providing these transfers $(\mathrm{C}(\mathrm{T}))$, plus any bribes $\mathrm{b}$ they may receive for giving funds $\mathrm{T}$ to a particular firm. Managers, on the other hand maximize utility equal to $\alpha(\pi+T-w L)-b$, where $\alpha$ is the $\%$ of the firm which is privately owned and $\pi$ is 
profits. We will begin by assuming that

$\alpha=1$.

In their QJE article, SV assume that managers and politicians bargain over EL and T in a Nash bargaining framework. SV also allow for (endogenously determined) bribes. The model is static. To make the model empirically tractable, we assume that $\mathrm{T}$ and $\mathrm{b}$ are predetermined, and that the managers and politicians only bargain over excess employment, EL. We will show that some key insights from their original article continue to hold.

If bargaining breaks down, we assume that politicians receive their disagreement utility, $\mathrm{U}_{0}{ }^{\mathrm{P}}$, and managers receive their disagreement utility $\mathrm{U}_{0}{ }^{\mathrm{M}}$. Under Nash bargaining, the two players maximize over EL the product:

$$
\left(B(E L)-C(T)+b-U_{0}^{P}\right)\left(\pi+T-w E L-b-U_{0}^{M}\right)
$$

If we assume a functional form for $\mathrm{B}(\mathrm{EL})=\mathrm{BwEL}$ and $\mathrm{C}(\mathrm{T})=\mathrm{CT}$, then the first order conditions from maximizing the above product can be rearranged to yield the following expression for wEL:

$$
\mathrm{wEL}=1 / 2\left\{\pi+\mathrm{T}(\mathrm{C} / \mathrm{B}+1)-\mathrm{b}(1+1 / \mathrm{B})-\mathrm{U}_{0}{ }^{\mathrm{M}}+\mathrm{U}_{0}{ }^{\mathrm{P}} / \mathrm{B}\right\}
$$

The expenditure on redundant or "excess" employees is positively correlated with firm profits, government transfers and the politician's threat point, but negatively correlated with bribes and the manager's threat point. In Section IV, we provide estimates for equation (9), using as a proxy for excess labor (wEL) the individual plant's deviation from the subsector's average expenditure share on labor for that year. 
It should be clear from equation (9) that public or private ownership is not the issue here; what determines excess employment (inefficiency) is the magnitude of transfers, bribes, and other factors. In fact, if we introduce ownership into this framework, we get perverse results-ie privatization leads to an increase in the use of excess labor (a decline in efficiency). To illustrate this point, we can allow $\alpha$ to vary between 0 and $1 . \mathrm{SV}$ assume that public sector managers only derive utility from the percentage of the firm's profits which are privately owned:

$$
\mathrm{U}^{\mathrm{M}}=\alpha(\pi+\mathrm{T}-\mathrm{wL})-\mathrm{b}
$$

If we rederive the first order conditions from the Nash bargaining game with $\alpha \neq 1$, we get the following:

$$
\mathrm{w}(\mathrm{EL})=1 / 2\left\{\pi+\mathrm{T}(\mathrm{C} / \mathrm{B}+1)-\mathrm{b}(1 / \alpha+1 / \mathrm{B})-\mathrm{U}_{0}^{\mathrm{M}} / \alpha+\mathrm{U}_{0}^{\mathrm{P}} / \mathrm{B}\right\}
$$

It is clear from (9)' that privatization (an increase in $\alpha$ ) will lead to an increase in wEL. Shifting so-called cash flow rights to firms lowers efficiency. The intuition is that increasing private ownership raises the utility that managers derive from plant profits, which weakens their bargaining position and allows the politician to extract more surplus relative to managers. SV derive a similar result. They use this result to argue that privatization-by which they mean transferring cash flow rights ( $\alpha$ becomes 1 ) to the firm-may have zero or even negative effects on efficiency.

$\mathrm{SV}$ also focus on the issue of control rights. In this context, control rights refer to who controls employment decisions if bargaining breaks down. Shifting control rights from the manager to the politician (and vice versa) changes the threat points and consequently the outcome 
of the bargaining game. We can show that in our simplified game, we get the same qualitative outcome as SV: shifting control rights from the politician to the manager reduces excess employment and raises efficiency. ${ }^{3}$

To incorporate the insights from SV into our framework, we need to combine equation (8) and equation (9)'. Equation (9)' states that wEL should be a function of transfers, bribes, the manager's and politician's threat points, and ownership. A parsimonious representation of equation (9)' is given by equation (10):

$$
w E L=\delta\left(\pi, T, b, \alpha, U_{0}{ }^{M}, U_{0}^{P}\right)
$$

To combine (10) with (8), we need to replace the expression $\mu \mathrm{B}_{\mathrm{NL}+\mathrm{EL}}\{\mathrm{dEL} /(\mathrm{NL}+\mathrm{EL})\}$ in equation (8) with (10) above. It is possible to show that $\mu \mathrm{B}_{\mathrm{NL}+\mathrm{EL}}\{\mathrm{dEL} /(\mathrm{NL}+\mathrm{EL})\}$ can be

${ }^{3} \mathrm{We}$ assume that if politicians control excess employment, then if bargaining breaks down they will set EL so that the utility of the manager, $\mathrm{U}^{\mathrm{M}}$, is set equal to zero. The manager will be compensated exactly so that $\pi+T-w E L-b=0$. If, on the other hand, the manager has control rights, we assume that when bargaining breaks down the manager will hire zero excess labor, get no transfers and give no bribes. In that case, we get that the utilities at the threat points are $\mathrm{U}_{0}^{\mathrm{M}=}$ $\pi$ and $\mathrm{U}_{0}{ }^{\mathrm{P}}=0$. Under politician control, the outcome of the Nash bargaining game is:

$$
\mathrm{w}(\mathrm{EL})=1 / 2\left\{\pi+\mathrm{T}(\mathrm{C} / \mathrm{B}+1)-\mathrm{b}(1+1 / \mathrm{B})+\mathrm{U}_{0}{ }^{\mathrm{P}} / \mathrm{B}\right\}
$$

Under manager control, the outcome of the Nash bargaining game is:

$$
\mathrm{w}(\mathrm{EL})=1 / 2\{\mathrm{~T}(\mathrm{C} / \mathrm{B}+1)-\mathrm{b}(1+1 / \mathrm{B})\}
$$

As long as profits are non-negative, it is clear that expenditure on excess labor will be higher under politician control. The different outcomes also provide a way to empirically identify who has control rights: under manager control, the firm's profits should not affect expenditure on excess labor. 
rewritten as $\rho[\mathrm{d}(\omega \mathrm{EL})]$ as long as the change in the real wage $\omega$ is close to zero. Combining the first difference of equation(10) with (8) yields the following:

$$
d \ln (Y)=d \ln A_{\text {true }}+\sum_{m=1 \text { to } M} \mu \mathrm{B}_{m} d \ln \left(Z_{m}\right)-\rho \mathrm{d} \delta\left(\pi, T, b, \alpha, U_{0}{ }^{M}, U_{0}{ }^{P}\right)
$$

E. Ownership Effects

For clarity, we now redefine public ownership, equal to $1-\alpha$, as PUB. We also reintroduce subscripts i for firm i and t for time t. Following Ehrlich et.al.(1994), we allow A to have the following components:

$A_{i t}=\exp \left(\eta_{1} P U B_{i t}+\eta_{2} P U B_{i t} *\right.$ time $\left.+\gamma X_{i t}+f_{i}+d_{t}+e_{i t}\right)$

The degree of public ownership, $P U B$, affects both the level and the growth rate of productivity. The coefficient on $P U B$ measures the relationship between ownership and the level of A; the coefficient on $P U B^{*}$ time measures the relationship between ownership and the change in A. The Ehrlich et.al. (1994) framework implies that the coefficient on PUB should be positive, while the coefficient on $P U B *$ time should be negative. We also include a vector $X$ of other factors, which could also affect productivity, and which we will discuss in more detail below. The framework in equation (12) allows for a plant-specific fixed effect, $f_{i}$, which reflects fixed differences across plants which are persistent but unobserved over time, time effects which are common to plants but which vary over time, $d_{t}$, and a random unobserved component, $e_{i t}$. 
To take into account the plant-specific effect, we could either include plant dummies in the estimation or take first-differences. We have chosen to do the latter. If we log-linearize equation (12) and transform it into first-differences, combining with (11) yields the following specification:

$$
\begin{aligned}
d l n(Y)_{i t} & =\eta_{1} d P U B_{i t}+\eta_{2} d\left(P U B_{i t}{ }^{*} \text { time }\right)+\gamma d X_{i t}+\sum_{m=1 \text { to } M} \mu \mathrm{B}_{m} d \ln \left(Z_{m i t}\right) \\
& -\rho d \delta\left(\pi, T, b, 1-P U B, U_{0}{ }^{M}, U_{0}{ }^{P}\right)_{i t}+d_{t}+e_{i t}
\end{aligned}
$$

In the specification above, ownership enters through two different avenues. First, it can affect Hicks neutral productivity growth by directly affecting managerial incentives. Second, ownership can affect the outcome of the game played between politicians and managers over excess labor. In Section IV, we begin by testing for the possibility that the relationship between excess employment and its determinants, as captured by equation (10), varies by ownership category.

A number of previous studies, especially the early studies, simply compare efficiency use across public and private plants of one factor, such as capital or labor. This is equivalent to estimating (13) in levels with $M=1$, ignoring the fixed effect, and setting all the $\gamma$ 's and $\rho$ 's as well as $\mathrm{B}_{2}$ through $\mathrm{B}_{M}$ equal to zero. Some examples of these studies are Boardman and Vining (1989), Funkhouser and MacAvoy (1979) and Groves, Hong, McMillan and Naughton (1994). ${ }^{4}$

${ }^{4}$ Boardman and Vining (1989) use sales per employee and sales per asset as measures of efficiency and find that private enterprises are more efficient, controlling for assets, number of employees, market share, concentration, country and industry. Funkhouser and MacAvoy (1979) analyze labor productivity and do not control for any other factors. They find that physical output per employee is higher private plants but sales or value-added per employee is lower. Groves, 
Ehrlich et al (1994) test for the impact of ownership by estimating a levels equation with plant fixed effects which includes ownership and the interaction of ownership with time.

Consistent with the predictions of their model, they find a negative and significant coefficient for the interaction between ownership and time, suggesting that total factor productivity growth is slower for public enterprises. But the coefficient on ownership alone is not robust, suggesting no clear relationship between TFP levels and public ownership. However, they ignore the soft budget constraint. Consequently, they do not test whether poor public sector performance is attributable purely to ownership or to the fact that public sector enterprises have access to subsidized loans.

\section{F. Other Environmental Factors}

Total factor productivity growth $(d \ln A)$ is likely to be affected by a number of factors which could enter via the vector X. Public sector enterprises are often established in sectors where the government seeks to regulate what would have been a natural monopoly. A different competitive environment is likely to directly affect the efficiency paramenter, $A$. To the extent that public sector enterprises operate in industries with high entry barriers, there is an omitted variable which could bias our results. The direction of the bias will depend on whether greater internal competition is likely to lead to higher or lower productivity. As a proxy for competition, we use the Herfindahl index. Despite its problems, it is the easiest measure to construct across

Hong, McMillan and Naughton (1994) find that giving Chinese enterprises greater autonomy (either by selling output outside state quotas or retaining a larger share of profits) does not lead to an increase in productivity but increasing the use of bonuses as a fraction of the wage bill and increasing the use of contract workers does. These results are consistent with Shleifer and Vishny (1994); giving managers cash flow rights without giving them control rights does not raise productivity because politicians have an incentive to use government transfers to extract political benefits (excess employment) from the firm. 
industries and over time.

Public sector enterprises are typically located in sectors which receive special protection from import competition. Consequently, failing to control for differences in import competition could lead to the incorrect conclusion that public sector enterprises are more inefficient, if lack of import competition is correlated with poor performance. To address this possibility, we constructed measures of import competition at the disaggregated industry level. Import penetration could have a direct impact on the Hicks neutral term dlnA, if plants subjected to import competition are more likely to innovate, use better quality inputs, or learn about better production techniques.

Finally, we also include in the vector $X$ a dummy variable which identifies stock market participation at the enterprise level. Laffont and Tirole (1993) argue that the kinds of problems that arise when there is separation of ownership and control can be mitigated by stock market participation. This is because the stock market provides at least a partial disciplining device to managers through stock prices. However, limited stock market participation, noisy prices, and different ownership structures can limit the amount of information such participation is likely to convey.

\section{Data}

We apply our framework to the manufacturing sector in Indonesia for the time period 1981-1995. Indonesia has a number of features which make it an interesting country to study. 
First, over this time period we are able to observe a trend towards privatization which allows us to examine the impacts of changes in ownership on enterprise performance. When Indonesia became independent in 1945, its constitution provided for government ownership of mineral resources and other "important" sectors of the economy. State enterprises were operated by indigenous Indonesians and the government's infusion of capital into these enterprises was viewed as a way of providing a counterweight to the Chinese firms that tended to dominate the private sector. ${ }^{5}$ During the early 1980 s, the government infused much capital into the state enterprise sector, facilitating its growth. But, beginning in the late 1980s and continuing into the early 1990s, a wave of privatizations occurred, ${ }^{6}$ so that by 1992 , the private sector in Indonesia became, for the first time, the driving force behind economic growth. ${ }^{7}$ A second feature of the Indonesian economy during this time period is a significant liberalization of trade in the late 1980s, which provides variation in the variable we use to measure external competition.

The Indonesian dataset that we use is a manufacturing census, which is conducted annually. Data are available for 1975 through 1995, but information on financing sources is only available beginning in 1981. The number of observations ranges from 6,258 in 1982 to over 12,904 in 1995. The dataset includes information on output, the number of skilled and unskilled workers, investment, material inputs, compensation, ownership, location, age and financing sources. Pitt and Lee (1981) used this dataset for the 1972-75 time period to study the impact of

\footnotetext{
${ }^{5}$ See Bresnan (1993), p. 253.

${ }^{6}$ The Fourth Five-Year Plan, announced in early 1984, called for an increased role for the private sector. Bresnan (1993), p. 254.

${ }^{7}$ Bresnan (1993), p. 264.
} 
foreign ownership on the productivity of weaving firms. Goeltom (1995) used the 1981-88 census data to study the impact of financial liberalization on efficiency in the manufacturing sector. We know of no attempt to use the Indonesian census to examine the relationship between public ownership and the soft budget constraint.

Data from the Indonesian census were merged with import and export data collected by the United Nations. Since the United Nations trade data (as made available to the World Bank), is available on an ISIC basis, it was possible to merge the two databases by three-digit ISIC. The United Nations data included information on both net exports and imports by ISIC. Import penetration (MPEN) was defined as imports divided by domestic production plus imports less exports. Domestic production was calculated by adding up enterprise-level production from the Census to the three-digit level. To avoid possibility endogeneity problems, we lagged MPEN one period. This variable is only available through 1993.

According to the framework developed in Section II, public sector firms which receive more financing from the government will exhibit lower productivity due to the hiring of unnecessary workers. We will proxy for transfers $\mathrm{T}$ using the share of the plant's investments that are financed by government loans (GLOAN). One limitation of this variable is that it only measures loans from the government and does not measure the transfer of government funds to public sector plants through direct grants or subsidies. ${ }^{8}$ However, anecdotal evidence suggests that government loans have a large subsidy component, and that many of these loans are never repaid at all. Another problem is that government loans may be endogeneous. If, for example,

\footnotetext{
${ }^{8}$ This is not a problem as long as the share of government loans in the total value of loans and subsidies is not correlated with the firm's productivity.
} 
government loans are simply extended to the weakest enterprises, then equation (13) could lead to a negative and significant coefficient on GLOAN. Since our goal is to identify the independent effects of a soft budget constraint on performance, we also provide instrumental variable estimates of the impacts of GLOAN on performance.

Table 2 provides some summary statistics from the Indonesian manufacturing census that compare the characteristics of private and public establishments. A private establishment is defined as one with 100 percent private (non-government) equity, while a public enterprise refers to establishments with any level of central or regional government equity participation. Table 2 shows that between 1981 and 1993 approximately 30 percent of public enterprise investment was financed by government loans, compared to only 1 to 2 percent for private firms. Note that by 1995, the share of public enterprise investment financed by government loans had fallen to 23 percent, because of the rise of alternative sources of financing. ${ }^{9}$ Over the entire time period 19811995, the percentage of government loans measured in rupiah that was allocated to the public sector was at least 70 percent, and rose to 96 percent by 1995, again as a likely result of the growth of private banks and the stock exchange. In the early 1980s, approximately 30 percent of public firms received government loans, but by 1995, only 13 percent were receiving loans from the government. Public sector enterprises, which accounted for 13-18 percent of total manufacturing output over the 1981-95 time period, are twice as old as private firms, at least four times as large, and have a higher ratio of skilled to unskilled workers.

\footnotetext{
${ }^{9} \mathrm{~A}$ series of reforms between 1988 and 1990 reduced the barriers to entry into the banking system and reduced the privileges of state banks. Forty new domestic banks were established between 1988 and 1990, and there was a dramatic growth in the Jakarta stock exchange, thereby providing new sources of investment financing. See Bresnan (1993), p.265.
} 
Table 3 provides information, by industrial sector, on the share of output accounted for by public enterprises and the percentage of investment financed by government loans in public and private enterprises. There are significant variations across sectors in the degree of private competition facing public enterprises. In some sectors, such as food products, industrial chemicals, and iron and steel, public enterprises account for a major share of production. In many other sectors, such as tobacco, apparel, footwear and professional equipment, public enterprises account for a small share of overall productive activity. Note that, even within the public sector, there are variations across industries in the share of investment financed by government loans. For example, in the food products industry, 47 percent of investment by public enterprises is financed by government loans, while in the industrial chemicals industry, only 22 percent of investment by public enterprises is financed by government loans.

Other Variable Definitions Equations (1) through (13), described in Section II, provide the framework for our empirical analysis. The dependent variable, Y, is measured by the real value of annual output. Inputs include the number of skilled production workers (SKILLED), the number of unskilled workers (UNSKILLED), the sum of the real value of domestically produced raw materials, imported raw materials, and energy used (MATERIALS), and the real value of investment (CAPITAL). ${ }^{10}$ Public ownership is measured by the percentage of equity owned by the central government or regional governments (PUB). Since public enterprises are less likely to raise funds on the stock exchange and firms that raise funds on the stock exchange may be

\footnotetext{
${ }^{10}$ The census data only reports the value of the capital stock for 1986 . We have chosen to proxy capital stock by investment. By doing this, we are in effect assuming either zero depreciation or that the omitted term, lagged capital stock multiplied by the rate of depreciation, does not induce any omitted variable bias. Clearly, proxying the change in the capital stock with investment is more appropriate for the first differences specification than for the levels.
} 
partially disciplined by the information revealed through share prices, we also add a dummy variable (STOCK) which equals one if the stock exchange is a source of investment financing for the firm. Finally, we include the age (AGE) of the firm.

Although we have no data on bribes $b$, we do have data on gifts at the plant level (GIFTS), which we shall use as a proxy for bribes. Although we considered using plant-level reported profits as our measure of $\pi$, to minimize endogeneity problems we instead use as a proxy for profits two sector-level measures, lagged one period: the herfindahl index (HERF) and import penetration (MPEN). Since higher concentration is typically associated with higher profits, we expect the coefficient on HERF to be positive, while since higher import competition is typically associated with lower profits, we expect the coefficient on MPEN to be negative. Both MPEN and HERF are lagged one period to avoid potential endogeneity problems. As we discussed in Section III, these variables could also affect productivity directly via the $\mathrm{X}$ vector, rather than operating through their impact on excess labor.

We do not observe disagreement points. However, since it is likely that firms with foreign equity participation bargain from a stronger position, the percentage of foreign investment (FOREIGN) is also included. Again, foreign ownership may have an independent effect on productivity since foreign-owned firms are likely to be more efficient than domestically owned firms. ${ }^{11}$ One factor likely to affect $\mathrm{U}_{0}{ }^{\mathrm{P}}$ is proximity of the plant to the capital, which we capture with a dummy variable JAVA which indicates whether or not the plant is located on the main

\footnotetext{
${ }^{11}$ Surprisingly, Pitt and Lee (1981) found that in the 1970s, Indonesian weaving firms that were foreign owned were less efficient than domestically owned firms in the industry.
} 
island. ${ }^{12}$

\section{Results}

\section{A. $\quad$ Testing SV: The Relationship between Transfers and Excess Employment}

We begin by examining whether there is support for the SV framework, which suggests that firms which receive subsidized loans "pay" for them by hiring too many employees-which then shows up as poor productivity growth. We do this by examining the relationship between excess employment and subsidized loans in the data, then examine the impact of loans on productivity directly.

Equation (10) suggests that there should be a positive relationship between expenditure on excess labor EL and transfers T, which we proxy with GLOAN. Although we do not directly observe EL, we do observe total expenditure on labor. Labor expenditure was first normalized simply by dividing by sales, to give a labor share in sales variable. However, labor share is not an appropriate measure for "excess" labor. To capture the idea of excess labor, we divided each firm's labor share by the annual mean labor share for each 3-digit manufacturing subsector. This alternative definition of labor share measures excess labor as the deviation from the sector mean.

Table 4 reports the means for raw labor share, as well as raw labor share normalized by

\footnotetext{
${ }^{12}$ It is difficult to predict the direction of the sign on this variable. On the main island we might expect larger gains from raising employment and smaller costs to raising taxes to finance subsidized loans. Alternatively, plants in remote regions may have little bargaining power relative to the regional bureaucrats who control the area. Other variables that could capture the political benefits from subsidizing additional employment would include unemployment, unionization and minimum wages (higher minimum wages are presumably tied to higher unemployment). It may be possible to get regional unemployment figures. Minimum wages also vary by region. We leave these additions for a later version of the paper.
} 
the sector mean, across public and private ownership. In column (1), which is restricted to the enterprises that did not receive government loans, we observe that the public sector enterprises have a higher share of labor costs in sales relative to private enterprises. This difference is more striking after controlling for sector means; private sector enterprises had a mean labor share which averaged 95 percent of sector means, compared to 109 percent for public sector enterprises.

According to the theoretical framework, excess labor should be higher in enterprises which received government support. The evidence in column (2) is consistent with that hypothesis for the public sector, but not for the private sector. Private sector enterprises which receive government loans hire fewer workers than other private sector enterprises. This trend is even stronger for the normalized labor shares, which drop from 95 percent of the industry average to 80 percent. For the public sector, however, there is an increase in excess labor, at least if labor shares are measured using the normalized shares. Public sector enterprises which receive government loans have labor shares in sales which are $14 \%$ above the industry average, compared to 9 percent above the industry average for public enterprises which do not receive such loans.

Table 5 presents raw pairwise correlations between changes in government loans and changes in labor share using both measures of labor shares. The findings show important differences between public and private enterprises. For private sector enterprises, there is no significant correlation between government loans and labor shares, however measured, but for public sector enterprises, the correlations are significant. The raw correlation is between 8 and 10 percent and is statistically significant at the 1 percent level.

The main conclusion from Tables 4 and 5 is that the relationship between government 
support and excess labor is quite different across public and private enterprises. ${ }^{13}$ Therefore, we will modify (10) to allow for different coefficients by ownership class. The empirical version of $w E L=\delta\left(\pi, T, b, \alpha, U_{0}^{M}, U_{0}^{P}\right)$, modified to allow the coefficients to vary across public and private owners, is given by:

$$
\begin{aligned}
w E L= & \delta_{1} G L O A N-\delta_{2} G I F T S+\delta_{3} H E R F-\delta_{4} M P E N-\delta_{5} F O R+\delta_{6} J A V A-\delta_{7} P U B \\
& +\delta_{8} P U B^{*} G L O A N-\delta_{9} P U B^{*} G I F T S+\delta_{10} P U B^{*} H E R F-\delta_{11} P U B^{*} M P E N-\delta_{12} P U B^{*} F O R \\
& +\delta_{13} P U B^{*} J A V A
\end{aligned}
$$

Transfers are proxied by GLOAN and bribes are captured by GIFTS. Determinants of profits include MPEN and HERF. We attempt to control for firm and politician threat points with the variables FOR and JAVA. The model suggests that the coefficients on GLOAN and HERF should be positive. The coefficients on MPEN, FOR, and GIFTS should be negative. The coefficient on JAVA is ambiguous.

The results are reported in Table 6. The evidence suggests that there is no independent impact of public ownership per se on the magnitude of excess employment, consistent with the preliminary evidence in Table 1 and with results presented later in the paper. The effect of public sector ownership on excess labor operates via government loans. The interactions between PUB and the two government loan measures are positive and significant in every equation in Table 6

\footnotetext{
${ }^{13}$ It is possible that government loans are used by the private sector to hire more capital so we do not observe an increase in labor shares for the private firms. This explanation of the observed difference between private and public sector firms would require the assumption that the private firms are more capital-constrained than the public firms.
} 
while the effect of government loans for private firms is zero or negative. Public sector firms which receive government loans spend more on employees, but this is not the case in the private sector. In other words, the SV framework is consistent with public enterprise behavior, but not with evidence for the private sector. Privatization matters because public enterprises hire too many employees in return for government support, but this game is not played in the private sector.

To take into account the fact that the SV model is only empirically relevant for public sector enterprises, we modify equation (13) by including the interaction of PUB with all the determinants of excess labor. ${ }^{14}$ To make the estimation somewhat more parsimonious, we drop the interaction between PUB and GIFTS, which was not significant in Table 6:

$$
\begin{aligned}
& d \ln (Y)_{i t}=\left(\eta_{1}+\rho \delta_{7}\right) d P U B_{i t}+\eta_{2} d\left(P U B_{i t} * \text { time }\right)+\sum_{m=1 \text { to } M} \mu \mathrm{B}_{m} d \ln \left(Z_{m i t}\right) \\
& \text { - } \rho \delta_{1} d G L O A N_{i t}+\rho \delta_{2} d G I F T S_{i t}-\left(\gamma_{1}+\rho \delta_{3}\right) d H E R F_{j t}+\left(\gamma_{2}+\rho \delta_{4}\right) d M P E N_{j t}+\rho \delta_{5} d F O R_{i t}- \\
& \rho \delta_{6} d J A V A_{i t}+\gamma_{3} d S T O C K_{i t}-\delta_{8} d\left(P U B^{*} G L O A N\right)_{i t}-\delta_{10} d(P U B * H E R F)_{i t}+ \\
& \delta_{11} d\left(P U B^{*} M P E N\right)_{i t}+\delta_{12} d\left(P U B^{*} F O R\right)_{i t}-\delta_{13} d\left(P U B^{*} J A V A\right)_{i t}+d_{t}+e_{i t}
\end{aligned}
$$

The results of estimating equation 13' are discussed in the next section.

\section{B. Effects of Public Ownership and Government Loans - OLS Results}

Although we derive our estimating equation (13)' in differences, we first report results of

\footnotetext{
${ }^{14}$ It must be acknowledged that there is a lot we do not know about the allocation of government loans; even in the levels specifications, the R-square is quite low.
} 
estimating a levels version of (13)', as shown in Table 7. Column (1) estimates the ownership effect without controlling for government loans. Column (2) controls for government loans and column (3) includes the other variables that we have argued are likely to be correlated with excess labor. ${ }^{15}$ In columns (4) and (5) the analysis excludes 1994 and 1995 in order to control for import penetration.

Consistent with the predictions of the Ehrlich model, we find positive coefficients on PUB and negative coefficients on its interaction with time that are significant in all equations except column (4). Using the results in column (5) we find that in 1981, a ten percentage point increase in public ownership would reduce efficiency by 1.1 percent, while in 1993, it would reduce it by 2.5\%. Hence, in 1993, a full privatization would increase the level of TFP by 25 percentage points. Government loans are found to have a negative effect on efficiency for both private and public firms with some evidence that this effect is stronger in the public sector. ${ }^{16}$

\section{C. $\quad$ Effects of Public Ownership and Government Loans - Fixed Effects Results}

It is problematic to compare productivity levels across plants because there could be a number of unobserved level effects leading to the observed differences between public and private enterprises: different prices, hidden subsidies, a different product mix, or a different regulatory environment. To the extent that these differences are fixed over time, the first difference specification, equation (13'), eliminates them. The results of estimating 13' are shown in Table 8.

\footnotetext{
${ }^{15}$ Note that an alternative model in which the government provides a wage subsidy to public sector firms would yield the specification in column (2) of Tables 7 and 8.

${ }^{16}$ The fact that the coefficient on GLOAN*PUB loses its significance in columns (3)-(5) is due to the inclusion of other variables that are correlated with EL and GLOAN.
} 
The main finding of Table 8 is that the effects of public ownership are no longer significant but the effect of GLOAN on public sector firms is negative and significant. According to the estimates in column (3), a ten percentage point increase in the share of investment funded by government loans lowers efficiency by .34 percentage points annually for an enterprise with 50 percent public ownership and by .84 percentage points for a fully public firm. The negative impact of government support for public enterprises is very large in magnitude: moving from zero to full government financing for a publicly owned enterprise would be associated with a reduction in total factor productivity growth of 8.4 percentage points annually. ${ }^{17}$ The results in Table 8 provide support for the argument that public sector enterprises are inefficient primarily due to the environment in which they operate, rather than any agency problem which is unique to public sector enterprises.

We also estimated the equations in Table 8 by three-digit subsector. To the extent that factor shares or mark-ups vary across sectors, the framework presented in equations (1)-(10) would justify presenting separate estimates by sector. Although many coefficients are insignificant due to small sample sizes, the sector-level results (not shown) are consistent with the aggregate results -particularly in sectors where there are enough observations with positive public ownership.

\section{Effects of Other Variables}

As predicted, if a firm uses the stock exchange as a source of investment funding, it is

\footnotetext{
${ }^{17}$ Using the estimates in column (4) would result in a reduction of 9.7 percentage points annually.
} 
more efficient. This holds for the OLS and the fixed effects models. Foreign-owned firms are more efficient according to the levels equations in Table 7 and the benefits of foreign ownership are even stronger for public sector firms. ${ }^{18}$ In the fixed effects model, the benefits of foreign ownership disappear for private sector firms but remain for the public enterprises. Although the Herfindahl index is positive and significant in the levels equations (greater concentration leading to greater efficiency), this effect disappears in the fixed effects models. Import penetration has a positive and significant effect for public sector firms in both Tables 7 and 8, indicating that public sector firms that were shielded from import competition had inferior performance. Finally, we observe that older firms are less efficient than younger ones.

\section{Instrumental Variable Estimates}

One possible source of mis-specification is the potential endogeneity of government loans. If loans are essentially bail-outs given to failing enterprises, then the negative coefficient on GLOAN suggests reverse causality: poor performance causes firms to receive transfers, but transfers need not have any independent effect on performance. Consequently, we re-estimated the productivity equations using an instrumental variables approach in which the instruments for GLOAN are the second lag of GLOAN, the lag of (first differenced) skilled labor, the lag of (first differenced) PUB*GLOAN, the lag of the first difference of skilled labor interacted with the lag of DPUB, the lag of unskilled labor interacted with the lag of DPUB, the lag of the first difference of material inputs interacted with the lag of DPUB, the lag of investment interacted with the lag of

\footnotetext{
${ }^{18} \mathrm{We}$ argue that foreign ownership is a good proxy for the manager's disagreement point and that enterprises with foreign ownership should have less excess employment.
} 
DPUB, the second lag of investment interacted with the lag of DPUB, the lag of DPUB, the lag of DGIFT, and the lag of DFOR. The results are shown in columns (2) and (4) of Table 9. For comparison purposes, columns (1) and (3) in that table show the ordinary least squares results for the same samples that are used for the instrumental variable analysis. This sample is smaller because of the necessity to include so many lags as instruments. The sample also eliminates plants with a very short time series.

With the instrumental variable estimates, the negative impact of government loans on the performance of public sector firms is very similar to the results reported with OLS. Comparing columns (1) and (2) we find that a ten percentage point increase in government financing of investment would reduce productivity growth by .29 percentage points for a fifty percent public

firm using IV and by .26 percentage points using OLS. Using columns (3) and (4), the estimates are .17 percentage points for IV and .20 percentage points for OLS. The IV results also confirm our earlier OLS results that private sector firms that receive government loans do not perform more poorly than other private sector enterprises. In sum, the results in Table 9 are consistent with no clear pattern of loan allocation which reflected bail-outs.

\section{Conclusions}

In this paper we disentangle the sources of public sector inefficiency using panel data for 1982 through 1995 on manufacturing firms in Indonesia. We consider two leading hypotheses: (1) public sector enterprises are inefficient due to monitoring problems and (2) public sector enterprises are inefficient because of the environment in which they operate, as measured by the 
soft budget constraint. We nest the two models in a production function framework and show that if the first model is correct, then public sector ownership will be associated with lower productivity growth. The second model implies that different types of ownership have no association with productivity; what matters is whether enterprises receive government subsidies in return for hiring excess labor.

We provide evidence that public sector firms that receive government loans hire excess labor but private firms that receive these loans do not. Most importantly, we show that public sector enterprises are inefficient because of their access to soft loans; public sector ownership had no independent impact on productivity growth. The finding that ownership per se does not matter, but environment does, holds when we control for fixed effects and when we allow for the endogeneity of government loans. Our results suggest that a ten percentage point increase in the share of investment funded by the government would lead to a decline in total factor productivity growth of .2 to .3 percentage points annually for a fifty percent public firm. Interestingly, private sector enterprises with access to government loans did not perform more poorly than other private sector enterprises. We also consider the role of another dimension of the environment, i.e. import penetration, and we find that public sector enterprises that have been shielded from import competition are inferior performers. In other words, our findings show that ownership matters only in environments in which government subsidies and/or barriers to external and internal competition exist.

These results underscore the importance of the environment in any reform effort which is targetted towards improving the performance of public enterprises. Our results also suggest that government financing of plant investment is likely to be more costly for public than for private 
enterprises. Many questions, however, remain unanswered. One of the most surprising results in this paper is that the negative impact of public sector ownership--independent of government loan support--is significant and large in levels but disappears in first differences. It remains to be seen whether this result is unique to Indonesia, a country where cronyism has been as endemic in the private as in the public sector. 


\section{Bibliography}

Barberis, Nicholas, Maxim Boycko, Andrei Shleifer and Natalia Tsukanova, "How Does Privatization Work? Evidence from the Russian Shops," Journal of Political Economy 104 (August 1996): 764-90.

Boardman, Anthony E. and Aidan R.Vining, "Ownership and Performance in Competitive Environments: A Comparison of the Performance of Private, Mixed, and State-Owned Enterprise, Journal of Law and Economics 32 (April 1989): 1-33.

Boubakri, Narjess and Jean-Claude Cosset, "The Financial and Operating Performance of Newly Privatized Firms: Evidence from Developing Countries", Journal of Finance, Vol. 53, No. 3, June 1998.

Bresnan, John, Managing Indonesia: The Modern Political Economy, Columbia University Press, New York, 1993.

Claessens, Stijn and Simeon Djankov, "Politicians and Firms: Evidence from Seven Central and Eastern European Countries, mimeo, 1997.

Ehrlich, Isaac, Georges Gallais-Hamonno, Zhiqiang Liu and Randall Lutter, "Productivity Growth and Firm Ownership: An Analytical and Empirical Investigation," Journal of Political Economy 102, (October 1994): 1006-1038.

Funkhouser, Richard and Paul W. MacAvoy, "A Sample of Observations on Comparative Prices in Public and Private Enterprises," Journal of Public Economics 11 (June 1979): 353-68.

Gertner, Robert H., David S. Scharfstein and Jeremy Stein, "Internal Versus External Capital Markets," Quarterly Journal of Economics (November 1994): 1211-1230.

Goeltom, Miranda, Indonesia's Financial Liberalization, Institute of Southeast Asian Studies, Singapore, 1995.

Griliches, Zvi and Jacques Mairesse, "Production Functions: The Search for Identification," mimeo, March 1995.

Groves, Theodore, Yongmiao Hong, John McMillan and Barry Naughton, "Autonomy and Incentives in Chinese State Enterprises," Quarterly Journal of Economics, (February 1994): 183-209.

Harrison, Ann E., "Productivity, Imperfect Competition and Trade Reform: Theory and Evidence," Journal of International Economics 36 (1994): 53-73.

Hubbard, R. Glenn and Darius Palia, "A Re-Examination of the Conglomerate Merger Wave in the 1960s: An Internal Capital Markets View,” Journal of Finance, June 1999. 
Kikeri, Sunita, John Nellis and Mary Shirley, "Privatization: Lessons from Market Economies," The World Bank Observer 9, (July 1994): 241-72.

La Porta, Rafael and Florencia Lopez-de-Silanes, "The Benefits of Privatization: Evidence from Mexico," NBER Working Paper 6215, October 1997.

Laffont, Jean-Jacques and Jean Tirole, A Theory of Incentives in Procurement and Regulation, The MIT Press, Cambridge, Massachusetts, 1993.

McGuckin, Robert H. and Sang V. Nguyen, "Post-Reform Industrial Productivity Performance of China: New Evidence from the 1985 Industrial Census Data," Economic Inquiry 31, (July 1993): 323-341.

Megginson, William L., Robert C. Nash, and Mathias van Randenborgh, "The Financial and Operating Performance of Newly Privatized Firms: An International Empirical Analysis," Journal of Finance, XLIX (1994): 403-52.

Pinto, Brian and Sweder van Wijnbergen, "Ownership and Corporate Control in Poland: Why State Firms Defied the Odds," CEPR Discussion Paper No. 1273, December 1995.

Pitt, Mark M. and Lung-Fei Lee, "The Measurement and Sources of Technical Inefficiency in the Indonesian Weaving Industry," Journal of Development Economics 9 (1981), 43-64.

Shleifer, Andrei and Robert W. Vishny, "Politicians and Firms," Quarterly Journal of Economics, (November 1994): 995-1025.

Vickers, John and George Yarrow, "Economic Perspectives on Privatization", The Journal of Economic Perspectives, Volume 5, Issue 2(Spring), 1991, 111-132. 
Table 1

Within Regressions for Privatizing Plants Only

\section{Dependent Variable}

Public Sector

Ownership

I. Profitability

Operating Income/Sales

Operating Income/Sales

Operating Income/Sales

Net Income/Sales

Net Income/Sales

Net Income/Sales

II. Operating Efficiency

Log (Sales)

Log (Sales)

Log (Sales)

Log (Sales/Employee)

Log (Sales/Employee)

Log (Sales/Employee)

Operating Income/Employee

Operating Income/Employee

$(-2.8)$

0.000

(0.2)

$-0.001$

$(-2.9)$

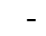

0.000

$(-0.8)$

$-0.003$

$(-2.8)$

$$
-
$$

0.000

(0.0)

$-0.001$

$(-1.2)$

0.000

(0.3)

$-15.242$

$(-2.4)$
Government Loans

Number of

Observations
798

661

$-0.021$

$(-1.0)$

$-0.021$

$(-0.9)$

$-$

$-.025$

$(-1.1)$

$-0.022$

$(-1.0)$

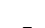

$-0.299$

$(-4.1)$

$-.298$

(-4.0)

$$
-
$$

0.166

$(-2.8)$

$-0.169$

(-2.8)

-

$-439.427$

(-0.8)
R-Square

.01

.00

.00

.01

.00

.00

.01

.03

.03

.00

.01

.01

.01

.00 


\begin{tabular}{|c|c|c|c|c|}
\hline Operating Income/Employee & $\begin{array}{c}-28.280 \\
(-2.9)\end{array}$ & $\begin{array}{c}-221.78 \\
(-0.4)\end{array}$ & 661 & .02 \\
\hline Log (Cost per Unit) & $\begin{array}{l}.001 \\
(2.5)\end{array}$ & - & 798 & .01 \\
\hline Log (Cost per Unit) & - & $\begin{array}{l}.038 \\
(2.1)\end{array}$ & 661 & .01 \\
\hline Log (Cost per Unit) & $\begin{array}{c}0.000 \\
(0.2)\end{array}$ & $\begin{array}{l}.038 \\
(1.9)\end{array}$ & 661 & .01 \\
\hline \multicolumn{5}{|l|}{ III. Labor } \\
\hline Log (Employees) & $\begin{array}{c}-0.002 \\
(-2.9)\end{array}$ & - & 798 & .01 \\
\hline Log (Employees) & - & $\begin{array}{c}-0.132 \\
(-2.9)\end{array}$ & 661 & .02 \\
\hline Log (Employees) & $\begin{array}{c}0.000 \\
(0.4)\end{array}$ & $\begin{array}{c}-0.129 \\
(-2.8)\end{array}$ & 661 & .02 \\
\hline Log (Skilled Workers) & $\begin{array}{c}0.000 \\
(0.1)\end{array}$ & - & 748 & .00 \\
\hline Log (Skilled Workers) & $\begin{array}{c}-0.164 \\
(-2.5)\end{array}$ & - & 620 & .01 \\
\hline Log (Skilled Workers) & $\begin{array}{c}0.000 \\
(0.2)\end{array}$ & $\begin{array}{c}-0.162 \\
(-2.4)\end{array}$ & 620 & .01 \\
\hline Log (Unskilled Workers) & $\begin{array}{l}-.001 \\
(-2.1)\end{array}$ & - & 798 & .01 \\
\hline Log (Unskilled Workers) & - & $\begin{array}{c}-0.069 \\
(-1.2)\end{array}$ & 661 & .00 \\
\hline Log (Unskilled Workers) & $\begin{array}{c}0.000 \\
(0.1)\end{array}$ & $\begin{array}{l}-.068 \\
(-1.2)\end{array}$ & 661 & .00 \\
\hline
\end{tabular}

Notes: T-statistics in parentheses. This table is restricted to those firms which fully privatized. Time period is 1981-1995. Coefficients are taken from a regression of different measures of performance on ownership and government loans, with all variables transformed into deviations from the individual plant mean over all years.

$\underline{\text { Variable Definitions: }}$

Public Sector Ownership

Government Loans

Employees

Skilled Workers

Unskilled Workers

Sales

Operating Income

Net Income

Cost of Sales

Cost Per Unit
Percentage of plant equity owned by the government. Varies between 0 and 100.

Ratio of amount of loans granted by government sources to total investment in plant in that year.

Total number of employees working at the plant

Non-production workers

Production workers

Sales are equal to the total value of products and services sold

Operating income is equal to sales minus operations expenses and cost of sales. We did not subtract depreciation expenses due to lack of data.

Net income is equal to operating income minus interest expenses and net taxes paid.

Cost of sales is equal to expenditure on materials and energy plus total compensation to unskilled workers

Ratio of Cost of Sales to Sales. 
Table 2

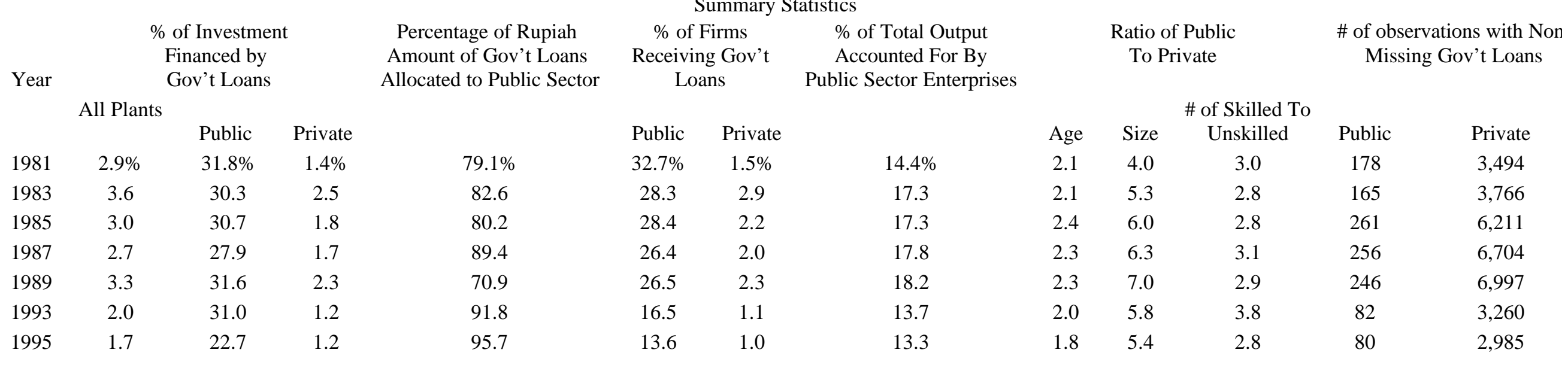


Table 3

Percentage of Output Produced

by Public Sector Enterprises

(All Years)
Percentage of Investment

Financed by Government Loans by ISIC Code (All Years)
(1)

\section{ISIC Code}

311 Food Products

312 Food Products, NEL

313 Beverages

314 Tobacco

321 Textiles

322 Apparel

323 Leather Products

324 Footwear

331 Wood Products

332 Furniture

341 Paper Products

342 Printing, Publishing

351 Industrial Chemicals

352 Other Chemicals

354 Petroleum Products

355 Rubber Products

356 Plastic Products

361 Pottery and China

362 Glass Products

369 Non-Metal Products

371 Iron \& Steel

372 Non-Ferrous Metals

381 Metal Products

382 Machinery, NEL

383 Electrical Machinery

384 Transport Equipment

385 Professional Equipment

390 Other Industries
$23.7 \%$

$4.6 \%$

$8.0 \%$

$0.2 \%$

$5.7 \%$

$0.2 \%$

$1.9 \%$

$0.6 \%$

$2.1 \%$

$1.0 \%$

$17.8 \%$

$7.1 \%$

$50.5 \%$

$2.0 \%$

$-$

$7.1 \%$

$0.1 \%$

$1.5 \%$

$11.1 \%$

$5.3 \%$

$62.1 \%$

$46.1 \%$

$11.6 \%$

$14.0 \%$

$10.0 \%$

$9.4 \%$

$0.3 \%$

$0.2 \%$
(2)

(3)

Public Sector Private Sector

$\begin{array}{cc}46.9 \% & 1.7 \% \\ 22.9 \% & 1.7 \% \\ 0 & 0.9 \% \\ 16.3 \% & 6.6 \% \\ 23.5 \% & 1.7 \% \\ 20.6 \% & 2.8 \% \\ 40.0 \% & 0.6 \% \\ 18.4 \% & 1.1 \% \\ 18.4 \% & 1.7 \% \\ 0 \% & 1.3 \% \\ 28.0 \% & 1.1 \% \\ 33.4 \% & 1.6 \% \\ 22.1 \% & 1.8 \% \\ 39.8 \% & 0.7 \%\end{array}$

$38.7 \%$

$2.2 \%$

$3.7 \% \quad 0.8 \%$

$3.8 \% \quad 1.2 \%$

$0 \quad 2.0 \%$

$17.8 \% \quad 1.3 \%$

$39.1 \% \quad 3.7 \%$

$21.5 \% \quad 0$

$19.4 \% \quad 1.2 \%$

$31.2 \% \quad 0.8 \%$

$23.0 \% \quad 0.7 \%$

$37.7 \% \quad 1.9 \%$

$0 \quad 1.4 \%$

$0 \quad 1.3 \%$ 
Table 4

Means For Labor Share Across Categories

No

Government Loans

(1)

Labor Share

Labor Share Normalized by Sector

Mean

Some Public Ownership

Labor Share

Labor Share Normalized by Sector

Mean

Notes: Labor Share is equal to total expenses on both skilled and unskilled labor, divided by sales. The normalized labor share is divided by the 3-digit sector mean for each year.

Some

Government Loans

(Loans $>0$ )

.80

$\begin{array}{ll}1.09 & 1.14\end{array}$ 
Table 5

Correlations Between Labor Share And Government Loans

No Public Sector Ownership

$\begin{array}{ccc}\text { Change in } & \text { Change in } & \text { Change in } \\ \text { Government Loans } & \text { Labor Share } & \text { Labor Share } \\ \text { As } \% \text { of Investment } & & \text { Normalized } \\ & & \text { by Sector Mean }\end{array}$

Change in Government Loans

as \% of Investment

1.0

Change in Labor Share

$-.01$

1.0

Change in Labor Share

.00

$.94 *$

1.0

Normalized by Sector Mean

Some Public Sector Ownership

$\begin{array}{ccc}\text { Change in } & \text { Change } & \text { Change } \\ \text { Government Loans } & \text { in } & \text { in } \\ \text { As \% of Investment } & \text { Labor Share } & \text { Labor Share } \\ & & \text { Normalized by } \\ & & \text { Sector Mean }\end{array}$

Change in Government Loans

as \% of Investment

1.0

Change in Labor Share

$.08^{*}$

1.0

Change in Labor Share

$.09 * \quad .96 *$

1.0

Normalized by Sector Mean

.Notes: See definitions for Table 4. A “*” indicates Statistically Significant at the $1 \%$ level. 
Table 6

Dependent Variable: Labor Share Normalized by Sector Mean

\begin{tabular}{|c|c|c|c|c|}
\hline & \multicolumn{2}{|c|}{ 1981-1993 } & \multicolumn{2}{|c|}{ 1981-1995 } \\
\hline & Levels & First Differences & Levels & First Differences \\
\hline & (1) & (2) & (3) & (4) \\
\hline $\begin{array}{l}\% \text { Public Ownership } \\
\quad \text { (PUB) }\end{array}$ & $\begin{array}{l}-0.523 \\
(-1.7)\end{array}$ & $\begin{array}{l}.245 \\
(1.2)\end{array}$ & $\begin{array}{l}-.047 \\
(.000)\end{array}$ & $\begin{array}{l}-.160 \\
(-1.0)\end{array}$ \\
\hline $\begin{array}{l}\text { Gov't Loans as \% of Investment } \\
\text { (GLOAN) }\end{array}$ & $\begin{array}{l}-.247 \\
(-10.6)\end{array}$ & $\begin{array}{l}-.009 \\
(-0.4)\end{array}$ & $\begin{array}{l}-.206 \\
(-10.5)\end{array}$ & $\begin{array}{l}-.014 \\
(-0.6)\end{array}$ \\
\hline Gifts & $\begin{array}{l}5.421 \\
(3.9)\end{array}$ & $\begin{array}{l}2.025 \\
(2.6)\end{array}$ & $\begin{array}{l}6.209 \\
(4.7)\end{array}$ & $\begin{array}{l}2.363 \\
(3.3)\end{array}$ \\
\hline $\begin{array}{l}\text { Foreign Ownership } \\
\quad \text { (FOR) }\end{array}$ & $\begin{array}{l}-.004 \\
(-22.8)\end{array}$ & $\begin{array}{l}.001 \\
(1.1)\end{array}$ & $\begin{array}{l}-.004 \\
(-23.7)\end{array}$ & $\begin{array}{c}0.000 \\
(0.0)\end{array}$ \\
\hline $\begin{array}{l}\text { Herf indahl Index }{ }_{t-1} \\
\quad(\text { HERF })\end{array}$ & $\begin{array}{l}.315 \\
(6.8)\end{array}$ & $\begin{array}{l}.037 \\
(0.5)\end{array}$ & $\begin{array}{l}.235 \\
(6.7)\end{array}$ & $\begin{array}{l}.098 \\
(1.6)\end{array}$ \\
\hline $\begin{array}{l}\text { Import Penetration }{ }_{\mathrm{t}-1} \\
\text { (MPEN) }\end{array}$ & $\begin{array}{l}.009 \\
(.127)\end{array}$ & $\begin{array}{l}.020 \\
(0.3)\end{array}$ & - & - \\
\hline Java Dummy & $\begin{array}{l}-.030 \\
(-2.9)\end{array}$ & $\begin{array}{l}-.013 \\
(-0.2)\end{array}$ & $\begin{array}{l}-.048 \\
(-6.0)\end{array}$ & $\begin{array}{l}.015 \\
(0.4)\end{array}$ \\
\hline PUB * GLOAN & $\begin{array}{l}.263 \\
(4.2)\end{array}$ & $\begin{array}{c}0.200 \\
(3.3)\end{array}$ & $\begin{array}{l}.261 \\
(4.7)\end{array}$ & $\begin{array}{l}.162 \\
(3.0)\end{array}$ \\
\hline PUB * GIFTS & $\begin{array}{c}-1.587 \\
(-0.5)\end{array}$ & $\begin{array}{l}-.190 \\
(-0.2)\end{array}$ & $\begin{array}{c}-1.640 \\
(-0.5)\end{array}$ & $\begin{array}{l}-.171 \\
(-0.1)\end{array}$ \\
\hline $\mathrm{PUB} * \mathrm{FOR}$ & $\begin{array}{l}-.010 \\
(-4.2)\end{array}$ & $\begin{array}{l}-.007 \\
(-0.8)\end{array}$ & $\begin{array}{l}-.010 \\
(-4.1)\end{array}$ & $\begin{array}{l}-.004 \\
(-0.7)\end{array}$ \\
\hline PUB $*$ HERF & $\begin{array}{c}-1.126 \\
(-3.4)\end{array}$ & $\begin{array}{l}.156 \\
(0.5)\end{array}$ & $\begin{array}{l}-861 \\
(-3.3)\end{array}$ & $\begin{array}{l}.253 \\
(1.1)\end{array}$ \\
\hline PUB * MPEN & $\begin{array}{l}-.533 \\
(-1.2)\end{array}$ & $\begin{array}{c}-1.314 \\
(-3.3)\end{array}$ & - & - \\
\hline PUB * JAVA & $\begin{array}{l}.061 \\
(1.0)\end{array}$ & $\begin{array}{l}-.395 \\
(-1.8)\end{array}$ & $\begin{array}{l}.117 \\
(2.3)\end{array}$ & $\begin{array}{l}-.096 \\
(-0.5)\end{array}$ \\
\hline Number of Observations & 45,101 & 27,487 & 66,840 & 39,920 \\
\hline R-Square & .03 & .01 & .03 & .01 \\
\hline
\end{tabular}

Notes: T-Values in parentheses. Standard errors are corrected for heteroskedasticity. All Specifications include year and sector (ISIC) dummies. 
Table 7

Impact of Ownership and the Soft Budget

Constraint on Productivity: Levels

Dependent Variable: Log Real Output

1981-1995

1981-1993

\begin{tabular}{|c|c|c|c|c|c|}
\hline & (1) & (2) & (3) & (4) & (5) \\
\hline PUB & $\begin{array}{l}.007 \\
(2.7)\end{array}$ & $\begin{array}{l}.008 \\
(2.9)\end{array}$ & $\begin{array}{l}.008 \\
(3.0)\end{array}$ & $\begin{array}{l}.004 \\
(1.2)\end{array}$ & $\begin{array}{l}.007 \\
(1.8)\end{array}$ \\
\hline PUB $* \mathrm{~T}$ & $\begin{array}{l}-.0001 \\
(-2.4)\end{array}$ & $\begin{array}{l}-.0001 \\
(-2.5)\end{array}$ & $\begin{array}{l}-.0001 \\
(-2.7)\end{array}$ & $\begin{array}{l}-.0005 \\
(-1.2)\end{array}$ & $\begin{array}{l}-.0001 \\
(-1.7)\end{array}$ \\
\hline Gloan & - & $\begin{array}{l}-.015 \\
(-1.0)\end{array}$ & $\begin{array}{l}-.021 \\
(-1.4)\end{array}$ & $\begin{array}{l}-.027 \\
(-1.6)\end{array}$ & $\begin{array}{l}-.027 \\
(-1.6)\end{array}$ \\
\hline Gloan * PUB & - & $\begin{array}{l}-.001 \\
(-2.0)\end{array}$ & $\begin{array}{c}-.0004 \\
(-1.4)\end{array}$ & $\begin{array}{c}-.0003 \\
(-1.1)\end{array}$ & $\begin{array}{l}-.0003 \\
(-1.0)\end{array}$ \\
\hline Skilled Labor & $\begin{array}{l}.144 \\
(57.1)\end{array}$ & $\begin{array}{l}.144 \\
(57.2)\end{array}$ & $\begin{array}{l}.142 \\
(56.5)\end{array}$ & $\begin{array}{l}.131 \\
(46.8)\end{array}$ & $\begin{array}{c}.131 \\
(46.9)\end{array}$ \\
\hline Unskilled Labor & $\begin{array}{c}.139 \\
(49.5)\end{array}$ & $\begin{array}{c}.139 \\
(49.5)\end{array}$ & $\begin{array}{c}.142 \\
(50.5)\end{array}$ & $\begin{array}{c}.139 \\
(46.7)\end{array}$ & $\begin{array}{c}.139 \\
(46.6)\end{array}$ \\
\hline Materials & $\begin{array}{c}.765 \\
(338.8)\end{array}$ & $\begin{array}{c}.765 \\
(338.7)\end{array}$ & $\begin{array}{c}.764 \\
(336.3)\end{array}$ & $\begin{array}{c}.777 \\
(314.5)\end{array}$ & $\begin{array}{c}.776 \\
(314.0)\end{array}$ \\
\hline Capital & $\begin{array}{l}.010 \\
(23.5)\end{array}$ & $\begin{array}{l}.010 \\
(23.5)\end{array}$ & $\begin{array}{l}.010 \\
(23.2)\end{array}$ & $\begin{array}{c}.009 \\
(19.9)\end{array}$ & $\begin{array}{l}.009 \\
(19.9)\end{array}$ \\
\hline Foreign Investment & $\begin{array}{l}.004 \\
(25.8)\end{array}$ & $\begin{array}{c}.004 \\
(25.8)\end{array}$ & $\begin{array}{l}.004 \\
(25.3)\end{array}$ & $\begin{array}{c}.003 \\
(22.2)\end{array}$ & $\begin{array}{c}.003 \\
(22.1)\end{array}$ \\
\hline $\begin{array}{l}\text { Herfindahl Index } \\
\text { (Lagged) }\end{array}$ & - & - & $\begin{array}{l}.174 \\
(8.2)\end{array}$ & $\begin{array}{l}.235 \\
(9.9)\end{array}$ & $\begin{array}{l}.228 \\
(9.6)\end{array}$ \\
\hline Stock Market Dummy & $\begin{array}{l}.026 \\
(1.8)\end{array}$ & $\begin{array}{l}.026 \\
(1.8)\end{array}$ & $\begin{array}{l}.026 \\
(1.8)\end{array}$ & $\begin{array}{l}.058 \\
(2.7)\end{array}$ & $\begin{array}{l}.057 \\
(2.7)\end{array}$ \\
\hline $\begin{array}{l}\text { Import Penetration } \\
\text { (Lagged) }\end{array}$ & - & - & - & $\begin{array}{l}.018 \\
(0.5)\end{array}$ & $\begin{array}{l}.029 \\
(0.8)\end{array}$ \\
\hline AGE & $\begin{array}{l}-.0008 \\
(-5.1)\end{array}$ & $\begin{array}{l}-.0008 \\
(-4.8)\end{array}$ & $\begin{array}{l}-.0007 \\
(-4.3)\end{array}$ & $\begin{array}{l}-.0004 \\
(-2.3)\end{array}$ & $\begin{array}{l}-.0004 \\
(-2.4)\end{array}$ \\
\hline GIFTS & - & - & $\begin{array}{l}-.259 \\
(-0.9)\end{array}$ & $\begin{array}{l}-.027 \\
(-0.1)\end{array}$ & $\begin{array}{l}-.041 \\
(-0.1)\end{array}$ \\
\hline JAVA & - & - & $\begin{array}{l}-.072 \\
(-15.3)\end{array}$ & $\begin{array}{l}-.067 \\
(-12.6)\end{array}$ & $\begin{array}{c}-.068 \\
(-12.8)\end{array}$ \\
\hline PUB * HERF & - & - & $\begin{array}{c}-.0002 \\
(-0.6)\end{array}$ & $\begin{array}{c}-.0006 \\
(-0.6)\end{array}$ & $\begin{array}{l}.001 \\
(1.1)\end{array}$ \\
\hline PUB * PEN & - & - & - & $\begin{array}{l}.002 \\
(3.6)\end{array}$ & - \\
\hline
\end{tabular}




\begin{tabular}{lccccc} 
PUB * FOR & - & - & .00005 & .00004 & .00004 \\
& & & $(2.8)$ & $(2.1)$ & $(2.4)$ \\
PUB * JAVA & - & - & -.0002 & -.0002 & -.0001 \\
& & & $(-0.6)$ & $(-0.8)$ & $(-0.3)$ \\
R-Square & .96 & .96 & .96 & .97 & .97 \\
Number of Observations & 50,429 & 50,429 & 50,235 & 37,072 & 37,072 \\
\hline
\end{tabular}

Note: t-values in parentheses. Standard errors are corrected for heteroskedasticity. All Specifications include year and ISIC dummies. Capital Stock is proxied by investment. 
Table 8

Impact of Ownership and the Soft Budget

Constraint on Productivity: First Differences

Dependent Variable: Log Change in Real Output

1982-1995

1982-1993

\begin{tabular}{|c|c|c|c|c|}
\hline & (1) & (2) & (3) & (4) \\
\hline DPUB & $\begin{array}{l}-.002 \\
(-0.4)\end{array}$ & $\begin{array}{l}-.001 \\
(-0.2)\end{array}$ & $\begin{array}{l}-.002 \\
(-0.3)\end{array}$ & $\begin{array}{l}-.010 \\
(-1.3)\end{array}$ \\
\hline $\mathrm{D}(\mathrm{PUB} * \mathrm{~T})$ & $\begin{array}{c}.00003 \\
(0.4)\end{array}$ & $\begin{array}{c}.00002 \\
(0.3)\end{array}$ & $\begin{array}{c}.00003 \\
(0.5)\end{array}$ & $\begin{array}{c}0.0001 \\
(1.3)\end{array}$ \\
\hline DGLOAN & - & $\begin{array}{l}.016 \\
(1.0)\end{array}$ & $\begin{array}{l}.016 \\
(1.0)\end{array}$ & $\begin{array}{l}.003 \\
(0.2)\end{array}$ \\
\hline D (GLOAN*PUB) & - & $\begin{array}{l}-.001 \\
(-2.8)\end{array}$ & $\begin{array}{l}-.001 \\
(-2.7)\end{array}$ & $\begin{array}{l}-.001 \\
(-2.7)\end{array}$ \\
\hline DSKILLED & $\begin{array}{c}.076 \\
(15.2)\end{array}$ & $\begin{array}{c}.076 \\
(15.2)\end{array}$ & $\begin{array}{c}.075 \\
(15.0)\end{array}$ & $\begin{array}{c}.074 \\
(12.4)\end{array}$ \\
\hline DUNSKILLED & $\begin{array}{l}.177 \\
(21.7)\end{array}$ & $\begin{array}{c}.177 \\
(21.8)\end{array}$ & $\begin{array}{l}.175 \\
(21.6)\end{array}$ & $\begin{array}{c}.174 \\
(18.3)\end{array}$ \\
\hline DMATERIALS & $\begin{array}{c}.633 \\
(84.3)\end{array}$ & $\begin{array}{c}.633 \\
(84.3)\end{array}$ & $\begin{array}{c}.633 \\
(83.9)\end{array}$ & $\begin{array}{c}.625 \\
(72.1)\end{array}$ \\
\hline DCAPITAL & $\begin{array}{l}.001 \\
(4.1)\end{array}$ & $\begin{array}{l}.001 \\
(4.1)\end{array}$ & $\begin{array}{l}.001 \\
(4.1)\end{array}$ & $\begin{array}{l}.002 \\
(3.7)\end{array}$ \\
\hline DFOREIGN & $\begin{array}{l}.0004 \\
(0.7)\end{array}$ & $\begin{array}{l}.0004 \\
(0.7)\end{array}$ & $\begin{array}{c}.0003 \\
(0.4)\end{array}$ & $\begin{array}{l}.0002 \\
(0.3)\end{array}$ \\
\hline $\mathrm{D}\left(\mathrm{HERF}_{\mathrm{t}-1}\right)$ & - & - & $\begin{array}{l}-.024 \\
(-0.6)\end{array}$ & $\begin{array}{c}-.042 \\
(-0.7)\end{array}$ \\
\hline DSTOCK & - & - & $\begin{array}{l}.040 \\
(2.6)\end{array}$ & $\begin{array}{l}.046 \\
(1.8)\end{array}$ \\
\hline $\mathrm{D}\left(\mathrm{MPEN}_{\mathrm{t}-1}\right)$ & - & - & - & $\begin{array}{l}.044 \\
(0.9)\end{array}$ \\
\hline DGIFTS & - & - & $\begin{array}{c}-1.051 \\
(-3.0)\end{array}$ & $\begin{array}{c}-0.851 \\
(-2.4)\end{array}$ \\
\hline DJAVA & - & - & $\begin{array}{l}-.196 \\
(-2.7)\end{array}$ & $\begin{array}{l}-.093 \\
(-1.0)\end{array}$ \\
\hline D(PUB*HERF) & - & - & $\begin{array}{l}-.003 \\
(-1.6)\end{array}$ & $\begin{array}{l}-.001 \\
(-0.4)\end{array}$ \\
\hline $\mathrm{D}(\mathrm{PUB} * \mathrm{PEN})$ & - & - & - & $\begin{array}{l}.004 \\
(2.3)\end{array}$ \\
\hline D(PUB*FOR) & - & - & $\begin{array}{l}.0003 \\
(2.7)\end{array}$ & $\begin{array}{l}.0003 \\
(2.7)\end{array}$ \\
\hline
\end{tabular}


D(PUB*JAVA)

R-Square

Number of Observations

Notes: T-Values in parentheses. Standard errors are corrected for heteroskedesticity. include year and ISIC dummies. The change in the capital stock is proxied by investment.
0.0

$(0.0)$

.62

22,986 
Table 9

Impact of Ownership and the Soft Budget Constraint on Productivity: Comparison of First Difference Instrumental Variable Estimates and OLS Estimates

Dependent Variable: Log Change in Real Output

\begin{tabular}{|c|c|c|c|c|}
\hline & \multicolumn{2}{|c|}{ 1982-1993 } & \multicolumn{2}{|c|}{ 1982-1995 } \\
\hline & OLS & IV & OLS & IV \\
\hline & (1) & (2) & (3) & (4) \\
\hline DPUB & $\begin{array}{l}-.015 \\
(-1.5)\end{array}$ & $\begin{array}{r}-.015 \\
(1.5)\end{array}$ & $\begin{array}{l}-.005 \\
(-0.7)\end{array}$ & $\begin{array}{l}-.003 \\
(-0.4)\end{array}$ \\
\hline $\mathrm{D}(\mathrm{PUB} * \mathrm{~T})$ & $\begin{array}{l}.0002 \\
(1.7)\end{array}$ & $\begin{array}{l}.0002 \\
(1.7)\end{array}$ & $\begin{array}{l}.0001 \\
(1.1)\end{array}$ & $\begin{array}{l}.0001 \\
(0.8)\end{array}$ \\
\hline DGLOAN & $\begin{array}{l}.024 \\
(1.1)\end{array}$ & $\begin{array}{l}.021 \\
(0.4)\end{array}$ & $\begin{array}{c}0.030 \\
(1.5)\end{array}$ & $\begin{array}{l}.083 \\
(1.9)\end{array}$ \\
\hline $\mathrm{D}(\mathrm{GLOAN} * \mathrm{PUB})$ & $\begin{array}{l}-.001 \\
(-2.8)\end{array}$ & $\begin{array}{l}-.001 \\
(-1.6)\end{array}$ & $\begin{array}{l}-.001 \\
(-2.6)\end{array}$ & $\begin{array}{l}-.002 \\
(-2.8)\end{array}$ \\
\hline DSKILLED & $\begin{array}{c}.077 \\
(10.1)\end{array}$ & $\begin{array}{c}.077 \\
(10.1)\end{array}$ & $\begin{array}{c}.078 \\
(12.1)\end{array}$ & $\begin{array}{c}.077 \\
(12.1)\end{array}$ \\
\hline DUNSKILLED & $\begin{array}{c}.165 \\
(13.2)\end{array}$ & $\begin{array}{c}.165 \\
(13.2)\end{array}$ & $\begin{array}{c}.168 \\
(16.0)\end{array}$ & $\begin{array}{c}.169 \\
(16.1)\end{array}$ \\
\hline DMATERIALS & $\begin{array}{c}.617 \\
(50.4)\end{array}$ & $\begin{array}{c}.617 \\
(50.4)\end{array}$ & $\begin{array}{c}.618 \\
(59.3)\end{array}$ & $\begin{array}{c}.618 \\
(59.3)\end{array}$ \\
\hline DCAPITAL & $\begin{array}{l}.001 \\
(2.6)\end{array}$ & $\begin{array}{l}.001 \\
(2.6)\end{array}$ & $\begin{array}{l}.002 \\
(3.4)\end{array}$ & $\begin{array}{l}.002 \\
(3.5)\end{array}$ \\
\hline DFOREIGN & $\begin{array}{l}.0001 \\
(0.2)\end{array}$ & $\begin{array}{l}.0001 \\
(0.2)\end{array}$ & $\begin{array}{l}.0001 \\
(0.1)\end{array}$ & $\begin{array}{l}.0001 \\
(0.1)\end{array}$ \\
\hline $\mathrm{D}\left(\mathrm{HERF}_{\mathrm{t}-1}\right)$ & $\begin{array}{c}-.095 \\
(1.5)\end{array}$ & $\begin{array}{l}-.095 \\
(-1.5)\end{array}$ & $\begin{array}{l}-.044 \\
(-1.0)\end{array}$ & $\begin{array}{l}-.043 \\
(-1.0)\end{array}$ \\
\hline DSTOCK & $\begin{array}{l}.039 \\
(1.9)\end{array}$ & $\begin{array}{l}.039 \\
(1.3)\end{array}$ & $\begin{array}{l}.040 \\
(2.3)\end{array}$ & $\begin{array}{l}.090 \\
(2.3)\end{array}$ \\
\hline $\mathrm{D}\left(\mathrm{MPEN}_{\mathrm{t}-1}\right)$ & $\begin{array}{l}.001 \\
(0.0)\end{array}$ & $\begin{array}{l}.001 \\
(0.0)\end{array}$ & - & - \\
\hline DGIFTS & $\begin{array}{l}-.646 \\
(-1.8)\end{array}$ & $\begin{array}{l}-.650 \\
(-1.8)\end{array}$ & $\begin{array}{l}-.801 \\
(-2.2)\end{array}$ & $\begin{array}{l}-.810 \\
(-2.2)\end{array}$ \\
\hline DJAVA & $\begin{array}{l}-.213 \\
(-1.0)\end{array}$ & $\begin{array}{l}-.213 \\
(-1.0)\end{array}$ & $\begin{array}{l}-.156 \\
(-1.5)\end{array}$ & $\begin{array}{l}-.158 \\
(-1.5)\end{array}$ \\
\hline
\end{tabular}




\begin{tabular}{lcccc} 
DPUB*HERF) & -.0003 & -.0001 & -.003 & -.003 \\
& $(-0.1)$ & $(-0.0)$ & $(-1.4)$ & - \\
D(PUB*PEN) & .005 & .005 & - & \\
& $(2.4)$ & $(2.4)$ & & .0003 \\
D(PUB*FOR) & .0003 & .0003 & .0003 & $(2.3)$ \\
& $(2.3)$ & $(2.2)$ & $(2.3)$ & -.002 \\
D(PUB*JAVA) & -0.003 & -.002 & -.002 & $-1.7)$ \\
& $(-1.0)$ & $(-0.9)$ & $(-1.7)$ & .62 \\
R-Square & .60 & .60 & .62 & 20,524 \\
Number of Observations & 14,494 & 14,494 & 20,524 & 4.1 \\
Chi-Square Value & - & 4.3 & - & \\
for Over-identification test & & & & \\
\hline
\end{tabular}

Notes: T-Values in parentheses. Standard errors are corrected for heteroskedesticity. All Specifications include year and ISIC dummies. All variables are in first differences. Instruments for GLOAN include the lag of DSKILLED, the lag of D(PUB * GLOAN), the lag of DSKILLED * the lag of DPUB, the lag of DUNSKILLED* the lag of DPUB, the lag of DMATERIALS* the lag of DPUB, the lag DCAPITAL* the lag of DPUB, the second lag of DCAPITAL* the lag of DPUB, the second lag of GLOAN, the lag of DPUB, the lag of DGIFT, and the lag of DFOR. 